\title{
Penerapan Asuhan Keperawatan Jiwa Dengan Masalah Kecemasan Pada Penderita Rheumatoid Arthritis: Studi Kasus
}

\author{
Chisca Sintya Manullang
}

Sintyaanggryani998@gmail.com

\section{BAB 1}

\section{PENDAHULUAN}

\subsection{Latar Belakang}

Rheumatoid Arthritis adalah nyeri yang diakibatkan karena adanya peradangan pada sendi bengkak, inflamasi atau telah terjadi kerusakan sehingga menimbulkan nyeri. Penderita nyeri rheumatoid arthritis terjadi karena adanya inflamasi yang disebabkan oleh proses imunologik pada sinovia yang mengakibatkan terjadinya sinovitis dan pembentukan pannus yang akhirnya mengakibatkan kerusakan sendi yang terjadi pada sel dan jaringan akan membebaskan berbagai mediator subtansi radang (Potter \& Perry, 2010).

Rheumatoid Arthritis adalah kondisi dimana sendi terasa nyeri akibat adanya peradangan yang disebabkan karena terjadinya gesekan ujung-ujung tulang penyusun sendi. Walaupun penyakit ini tidak menyebabkan kematian, namun dapat mengakibatkan masalah medik seperti nyeri, psikologis yang bisa menimbulkan cemas karena rasa nyeri, sulit tidur dan gelisah, serta terganggunya interaksi di lingkungan sekitar. Penanganan nyeri pada lansia dengan rheumatoid arthritis merupakan hal yang perlu mendapatkan perhatian karena jika penanganan nyeri benar dan tepat, maka nyeri rheumatoid arthritis dapat terkontrol, dan terhindar dari komplikasi seperti gangguan fungsi bahkan kelumpuhan (Diah \& Masruroh, 2021).

Rhoeumatoid Arthritis (RA) merupakan penyakit autoimun yang ditandai oleh inflamasi sistematik kronik dan progresif dengan target utama adalah sendi. Sendi yang dikenai terutama sendi kecil dan menegah secara simetris. Rheumatoid arthritis tidak hanya mengenai lapisan synoval sendi juga tetapi juga dapat mengenai organ-organ diluar persendian seperti kulit, jantung, kulit, dan paru-paru dan mata (Purqan, 2019). 
Rheumatoid Arthritis biasanya terjadi di sendi tangan, siku, kaki, dan lutut sehingga terjadi nyeri dan bengkak pada bagian sendi. dan secara terus-menerus dan semakin lama gejala keluhannya terasa semakin berat dan menyebabkan terjadinya hambatan mobilitas fisik sehingga dengan terjadinya penyakit RA pada pasien maka pasien merasa cemas karena penyakit yang dideritanya.

Rheumatoid Arthritis biasanya terjadi di sendi tangan, siku, kaki, dan lutut sehingga terjadi nyeri dan bengkak pada bagian sendi. dan secara terus-menerus dan semakin lama gejala keluhannya terasa semakin berat dan menyebabkan terjadinya hambatan mobilitas fisik. Rheumatoid arthritis dapat mempengaruhi sendi apapun, sendi-sendi kecil di tangan dan kaki cenderung paling sering terlibat. Pada rheumatoid arthritis kekakuan paling sering terburuk di pagi hari. Hal ini dapat berlangsung satu sampai dua jam atau bahkan sepanjang hari. Kekakuan untuk waktu yang lama di pagi hari tersebut merupakan petunjuk bahwa seseorang mungkin memiliki rheumatoid arthritis, karena sedikit penyakit arthritis lainnya berperilaku seperti ini. Misalnya, osteoarthritis paling sering tidak menyebabkan kekakuan pagi yang berkepanjangan sehingga pasien merasakan kecemasan dalam dirinya.

Kecemasan merupakan suatu keadaan perasaan gelisah, ketidaktentuan, ada rasa takut dari kenyataan atau persepsi ancaman sumber aktual yang tidak diketahui masalahnya (Pardede \& Simangunsong, 2020). Kecemasan merupakan suatu respon psikologis maupun fisiologis individu terhadap suatu keadaan yang tidak menyenangkan, atau reaksi atas situasi yang dianggap mengancam (Hulu \& Pardede, 2016).

Kecemasan (anxiety) merupakan perasaantakut yang tidak jelas penyebabnya dan tidak didukung oleh situasi yang ada. Kecemasan dapat dirasakan oleh setiap orang jika mengalami tekanan dan perasaan mendalam yang menyebabkan masalah psikiatrik dan dapat berkembang dalam jangka waktu lama. (Marbun, Pardede \& Perkasa, 2019). Kecemasan yang terjadi tidak saja dialami oleh seorang pasien tetapi dapat juga dialami oleh perawat karena perawat terkadang cemas ketika berhadapan dengan pasien dan keluarga pasien Pardede, Keliat, Damanik, \& Gulo (2020).

Menurut world Health Organization (WHO) pravelensi penyakit Rheumatid Arhtritis bervariasi antara $0,3 \%$ dan $1 \%$ dan lebih sering terjadi dinegara maju dalam 10 Tahun 
sejak onset, setidaknya 50\% pasien di negara - negara maju tidak dapat mempertahankan pekerjaan penuh waktu (WHO, 2019). Pravelensi penyakit arthritis Rheumatoid berdasarkan diangnosis di indonesia $11,9 \%$ dan berdasarkan diangnosis gejala $24,7 \%$ pravelensi berdasarkan diangnosis tertinggi dibali 19,3\% diikuti aceh 18,3\% jawa Barat $17,5 \%$ dan papua $15,4 \%$ p revalensi penyakit arthritis Rehumatoid berdasarkan diagnosis tertinggi diNusa tenggara timur 33,1\% diikuti jawa barat 32,1\% dan bali (WHO, 2019).

Jumlah penduduk Sumatera Utara tahun 2009 yaitu 13.248.386 jiwa dan 29,17\% adalah lansia. Dari beberapa kabupaten dan kota di Sumatera Utara,jumlah penduduk terbanyak terdapat di Kota Medan yaitu 2.121.053. jiwa dan 35,07\% adalah lansia dengan angka kejadian arthritis reumatoid 30\% di Kota Medan (Torich, 2011 dalam Simbolon, M. E, 2021).

Berdasarkan survei awal pada pasien di Tanjung Anom, didapatkan bahwa pasien terlihat gelisah dan selalu cemas akibat mengalami penyakit Rheumatoid Arthritis (RA) sejak 2 tahun yang lalu.

\subsection{Tujuan}

\subsubsection{Tujuan Umum}

Untuk memberikan asuhan keperawatan pada Tn. A dengan masalah kecemasan

\subsubsection{Tujuan Khusus}

1. Mahasiswa mampu melakukan pengkajian pada Tn.A dengan masalah kecemasan.

2. Mahasiswa mampu menegakkan diagnosa pada Tn.A dengan masalah kecemasan.

3. Mahasiswa mampu membuat intervensi pada Tn.A dengan masalah kecemasan.

4. Mahasiswa mampu melakukan implementasi pada Tn.A dengan masalah kecemasan.

5. Mahasiswa mampu membuat evaluasi pada Tn.A dengan masalah kecemasan. 


\section{BAB 2 \\ TINJAUAN TEORITIS}

\subsection{Konsep Rheumatoid Arthritis}

\subsubsection{Definisi Rheumatoid Arthritis}

Kata arthritis berasal dari bahasa Yunani, "arthon" yang berarti sendi, dan "itis" yang berarti peradangan. Secara harfiah, arthritis berarti radang pada sendi. Sedangkan Rheumatoid Arthritis adalah suatu penyakit autoimun dimana persendian (biasanya tangan dan kaki) mengalami peradangan, sehingga terjadi pembengkakan, nyeri dan seringkali menyebabkan kerusakan pada bagian dalam sendi (Febriana, 2015).

Rheumatoid Arthritis (RA) adalah penyakit autoimun yang etiologinya belum diketahui dan ditandai oleh sinovitis erosif yang simetris dan pada beberapa kasus disertai keterlibatan jaringan ekstraartikular. Perjalanan penyakit RA ada 3 macam yaitu monosiklik, polisiklik dan progresif. Sebagian besar kasus perjalananya kronik kematian dini (Rekomendasi Perhimpunan Reumatologi Indonesia, 2014). Penyakit ini sering menyebabkan kerusakan sendi, kecacatan dan banyak mengenai penduduk pada usia produktif sehingga memberi dampak sosial dan ekonomi yang besar. Diagnosis dini sering menghadapai kendala karena pada masa dini sering belum didapatkan gambaran karakteristik yang baru akan berkembang sejalan dengan waktu dimana sering sudah terlambat untuk memulai pengobatan yang adekuat (Febriana, 2015).

\subsubsection{Faktor Risiko Rheumatoid Arthritis}

Faktor risiko yang berhubungan dengan peningkatan kasus RA dibedakan menjadi dua yaitu faktor risiko yang tidak dapat dimodifikasi dan faktor risiko yang dapat dimodifikasi :

1) Tidak Dapat Dimodifikasi

a. Faktor genetik

Faktor genetik berperan $50 \%$ hingga $60 \%$ dalam perkembangan RA. Gen yang berkaitan kuat adalah HLA-DRB1. Selain itu juga ada gen tirosin fosfatase PTPN 22 di kromosom 1. Perbedaan substansial pada faktor genetik RA terdapat diantara populasi Eropa dan Asia. HLADRB1 terdapat di seluruh populasi penelitian, sedangkan polimorfisme PTPN22 teridentifikasi di 
populasi Eropa dan jarang pada populasi Asia. Selain itu ada kaitannya juga antara riwayat dalam keluarga dengan kejadian RA pada keturunan selanjutnya.

b. Usia RA biasanya timbul antara usia 40 tahun sampai 60 tahun. Namun penyakit ini juga dapat terjadi pada dewasa tua dan anak-anak (Rheumatoid Arthritis Juvenil). Dari semua faktor risiko untuk timbulnya RA, faktor ketuaan adalah yang terkuat. Prevalensi dan beratnya RA semakin meningkat dengan bertambahnya usia. RA hampir tak pernah pada anak-anak, jarang pada usia dibawah 40 tahun dan sering pada usia diatas 60 tahun.

c. Jenis kelamin RA jauh lebih sering pada perempuan dibanding laki-laki dengan rasio $3: 1$. Meskipun mekanisme yang terkait jenis kelamin masih belum jelas. Perbedaan pada hormon seks kemungkinan memiliki pengaruh.

2) Dapat Dimodifikasi

a. Gaya hidup

\section{Status sosial ekonomi}

Penelitian di Inggris dan Norwegia menyatakan tidak terdapat kaitan antara faktor sosial ekonomi dengan RA, berbeda dengan penelitian di Swedia yang menyatakan terdapat kaitan antara tingkat pendidikan dan perbedaan paparan saat bekerja dengan risiko RA.

2. Merokok

Sejumlah studi cohort dan case-control menunjukkan bahwa rokok tembakau berhubungan dengan peningkatan risiko RA. Merokok berhubungan dengan produksi dari rheumatoid factor (RF) yang akan berkembang setelah 10 hingga 20 tahun. Merokok juga berhubungan dengan gen ACPA-positif RA dimana perokok menjadi 10 hingga 40 kali lebih tinggi dibandingkan bukan perokok. Penelitian pada perokok pasif masih belum terjawab namun kemungkinan peningkatan risiko tetap ada.

3. Diet

Banyaknya isu terkait faktor risiko RA salah satunya adalah makanan yang mempengaruhi perjalanan RA. Dalam penelitian Pattison dkk, isu mengenai faktor diet ini masih banyak ketidakpastian dan jangkauan yang terlalu lebar mengenai jenis makanannya. Penelitian tersebut menyebutkan daging merah dapat meningkatkan risiko RA sedangkan buah-buahan dan minyak ikan memproteksi kejadian RA. Selain itu 
penelitian lain menyebutkan konsumsi kopi juga sebagai faktor risiko namun masih belum jelas bagaimana hubungannya.

4. Infeksi

Banyaknya penelitian mengaitkan adanya infeksi Epstein Barr virus (EBV) karena virus tersebut sering ditemukan dalam jaringan synovial pada pasien RA. Selain itu juga adanya parvovirus B19, Mycoplasma pneumoniae, Proteus, Bartonella, dan Chlamydia juga memingkatkan risiko RA.

5. Pekerjaan

Jenis pekerjaan yang meningkatkan risiko RA adalah petani, pertambangan, dan yang terpapar dengan banyak zat kimia namun risiko pekerjaan tertinggi terdapat pada orang yang bekerja dengan paparan silica.

b. Faktor hormonal

Hanya faktor reproduksi yang meningkatkan risiko RA yaitu pada perempuan dengan sindrom polikistik ovari, siklus menstruasi ireguler, dan menarche usia sangat muda.

c. Bentuk tubuh Risiko RA meningkat pada obesitas atau yang memiliki Indeks Massa Tubuh (IMT) lebih dari 30.

\subsubsection{Etiopatogenesis dan Patofisiologi Rheumatoid Arthritis}

Penyebab pasti masih belum diketahui secara pasti dimana merupakan penyakit autoimun yang dicetuskan faktor luar (infeksi, cuaca) dan faktor dalam (usia, jenis kelamin, keturunan, dan psikologis). Diperkirakan infeksi virus dan bakteri sebagai pencetus awal RA. Sering faktor cuaca yang lembab dan daerah dingin diperkirakan ikut sebagai faktor pencetus. Patogenesis terjadinya proses autoimun, yang melalui reaksi imun komplek dan reaksi imunitas selular. Tidak jelas antigen apa sebagai pencetus awal, mungkin infeksi virus. Terjadi pembentukan faktor rematoid, suatu antibodi terhadap antibodi abnormal, sehingga terjadi reaksi imun komplek (autoimun). Proses autoimun dalam patogenesis RA masih belum tuntas diketahui, dan teorinya masih berkembang terus. Dikatakan terjadi berbagai peran yang saling terkait, antara lain peran genetik, infeksi, autoantibodi serta peran imunitas selular, humoral, peran sitokin, dan berbagai mediator keradangan. Semua peran ini, satu sam lainnya saling terkait dan pada akhirmya menyebabkan keradangan pada sinovium 
dan kerusakan sendi disekitarnya atau mungkin organ lainnya. Sitokin merupakan local protein mediator yang dapat menyebabkan pertumbuhan, diferensiasi dan aktivitas sel, dalam proses keradangan. Berbagai sitokin berperan dalam proses keradangan yaitu TNF $\alpha$, IL-1, yang terutama dihasilkan oleh monosit atau makrofag menyebabkan stimulasi dari sel mesenzim seperti sel fibroblast sinovium, osteoklas, kondrosit serta merangsang pengeluaran enzim penghancur jaringan, enzim matrix metalloproteases (MMPs) (Putra dkk,2013).

Proses keradangan karena proses autoimun pada RA, ditunjukkan dari pemeriksaan laboratorium dengan adanya RF (Rheumatoid Factor) dan anti-CCP dalam darah. RF adalah antibodi terhadap komponen Fc dari IgG. Jadi terdapat pembentukan antibodi terhadap antibodi dirinya sendiri, akibat paparan antigen luar, kemungkinan virus atau bakteri. RF didapatkan pada 75 sampai $80 \%$ penderita RA, yang dikatakan sebagai seropositive. Anti-CCP didapatkan pada hampir 2/3 kasus dengan spesifisitasnya yang tinggi (95\%) dan terutama terdapat pada stadium awal penyakit. Pada saat ini RF dan anti-CCP merupakan sarana diagnostik penting RA dan mencerminkan progresifitas penyakit (Putra dkk,2013). Sel B, sel T, dan sitokin pro inflamasi berperan penting dalam patofisiologi RA. Hal ini terjadi karena hasil diferensiasi dari sel T merangsang pembentukan IL-17, yaitu sitokin yang merangsang terjadinya sinovitis. Sinovitis adalah peradangan pada membran sinovial, jaringan yang melapisi dan melindungi sendi. Sedangkan sel B berperan melalui pembentukan antibodi, mengikat patogen, kemudian menghancurkannya. Kerusakan sendi diawali dengan reaksi inflamasi dan pembentukan pembuluh darah baru pada membran sinovial. Kejadian tersebut menyebabkan terbentuknya pannus, yaitu jaringan granulasi yang terdiri dari sel fibroblas yang berproliferasi, mikrovaskular dan berbagai jenis sel radang. Pannus tersebut dapat mendestruksi tulang, melalui enzim yang dibentuk oleh sinoviosit dan kondrosit yang menyerang kartilago. Di samping proses lokal tersebut, dapat juga terjadi proses sistemik. Salah satu reaksi sistemik yang terjadi ialah pembentukan protein fase akut (CRP), anemia akibat penyakit kronis, penyakit jantung, osteoporosis serta mampu mempengaruhi hypothalamic-pituitaryadrenalaxis, sehingga menyebabkan kelelahan dan depresi (Choy, 2012).

Pada keadaan awal terjadi kerusakan mikrovaskular, edema pada jaringan di bawah sinovium, poliferasi ringan dari sinovial, infiltrasi PMN, dan penyumbatan pembuluh 
darah oleh sel radang dan trombus. Pada RA yang secara klinis sudah jelas, secara makros akan terlihat sinovium sangat edema dan menonjol ke ruang sendi dengan pembentukan vili. Secara mikros terlihat hiperplasia dan hipertropi sel sinovia dan terlihat kumpulan residual bodies. Terlihat perubahan pembuluh darah fokal atau segmental berupa distensi vena, penyumbatan kapiler, daerah trombosis dan pendarahan perivaskuler. Pada RA kronis terjadi kerusakan menyeluruh dari tulang rawan, ligamen, tendon dan tulang. Kerusakan ini akibat dua efek yaitu kehancuran oleh cairan sendi yang mengandung zat penghancur dan akibat jaringan granulasi serta dipercepat karena adanya Pannus (Putra dkk,2013).

\subsubsection{Manifestasi Klinis, Pemeriksaan Penunjang dan Diagnosis Rheumatoid Arthritis}

1) Manifestasi Klinis

Keluhan biasanya mulai secara perlahan dalam beberapa minggu atau bulan. Sering pada keadan awal tidak menunjukkan tanda yang jelas. Keluhan tersebut dapat berupa keluhan umum, keluhan pada sendi dan keluhan diluar sendi (Putra dkk,2013).

a. Keluhan umum

Keluhan umum dapat berupa perasaan badan lemah, nafsu makan menurun, peningkatan panas badan yang ringan atau penurunan berat badan.

b. Kelainan sendi

Terutama mengenai sendi kecil dan simetris yaitu sendi pergelangan tangan, lutut dan kaki (sendi diartrosis). Sendi lainnya juga dapat terkena seperti sendi siku, bahu sterno-klavikula, panggul, pergelangan kaki. Kelainan tulang belakang terbatas pada leher. Keluhan sering berupa kaku sendi di pagi hari, pembengkakan dan nyeri sendi.

c. Kelainan diluar sendi

1. Kulit : nodul subukutan (nodul rematoid)

2. Jantung : kelainan jantung yang simtomatis jarang didapatkan, namun $40 \%$ pada autopsi RA didapatkan kelainan perikard

3. Paru : kelainan yang sering ditemukan berupa paru obstruktif dan kelainan pleura (efusi pleura, nodul subpleura)

4. Saraf : berupa sindrom multiple neuritis akibat vaskulitis yang sering terjadi berupa keluhan kehilangan rasa sensoris di ekstremitas dengan gejala foot or wrist drop 
5. Mata : terjadi sindrom sjogren (keratokonjungtivitis sika) berupa kekeringan mata, skleritis atau eriskleritis dan skleromalase perforans

6. Kelenjar limfe: sindrom Felty adalah RA dengan spleenomegali, limpadenopati, anemia, trombositopeni, dan neutropeni.

2) Pemeriksaan Penunjang

1. Laboratorium

a. Penanda inflamasi : Laju Endap Darah (LED) dan C-Reactive Protein (CRP) meningkat

b. Rheumatoid Factor (RF) : $80 \%$ pasien memiliki RF positif namun RF negatif tidak menyingkirkan diagnosis

c. Anti Cyclic Citrullinated Peptide (anti CCP) : Biasanya digunakan dalam diagnosis dini dan penanganan RA dengan spesifisitas 95-98\% dan sensitivitas $70 \%$ namun hubungan antara anti CCP terhadap beratnya penyakit tidak konsisten

2. Radiologis Dapat terlihat berupa pembengkakan jaringan lunak, penyempitan ruang sendi, demineralisasi "juxta articular", osteoporosis, erosi tulang, atau subluksasi sendi.

3) Diagnosis

Terdapat beberapa kesulitan dalam mendeteksi dini penyakit RA. Hal ini disebabkan oleh onset yang tidak bisa diketahui secara pasti dan hasil pemeriksaan fisik juga dapat berbeda-beda tergantung pada pemeriksa. Meskipun demikian, penelitian sebelumnya telah menunjukkan bahwa alat ukur diagnosis RA dengan ARA (American Rheumatism Association) yang direvisi tahun 1987 memiliki sensitivitas $91 \%$. Hasil laboratorium yang digunakan dalam mendiagnosis RA ditemukan kurang sensitif dan spesifik. Sebagai contoh, IGM Rheumatoid Factor memiliki spesifisitas 90\% dan sensitivitas hanya 54\% (Bresnihan, 2002).

Berikut adalah kriteria ARA (American Rheumatism Association) yang direvisi tahun 1987 yang masih dapat digunakan dalam mendiagnosis RA:

a. Kaku pagi hari pada sendi dan sekitarnya, sekurang-kurangnya selama 1 jam sebelum perbaikan maksimal.

b. Pembengkakan jaringan lunak atau persendian (arthritis) pada 3 daerah sendi atau lebih secara bersamaan. 
c. Artritis pada persendian tangan sekurang-kurangnya terjadi satu pembengkakan persendian tangan yaitu PIP (proximal interphalangeal), MCP (metacarpophalangeal), atau pergelangan tangan.

d. Artritis simetris, keterlibatan sendi yang sama pada kedua belah sisi misalnya PIP (proximal interphalangeal), MCP (metacarpophalangeal), atau MTP (metatarsophalangeal).

e. Nodul rheumatoid, yaitu nodul subkutan pada penonjolan tulang atau permukaan ekstensor atau daerah juksta artikuler.

f. Rheumatoid Factor serum positif

g. Perubahan gambaran radiologis yang khas pada RA pada sendi tangan atau pergelangan tangan yaitu erosi atau dekalsifikasi tulang pada sendi yang terlibat Diagnosa RA, jika sekurang-kurangnya memenuhi 4 dari 7 kriteria di atas dan kriteria 1 sampai 4 harus ditemukan minimal 6 minggu. Selain kriteria diatas, dapat pula digunakan kriteria diagnosis RA berdasarkan skor dari American College of Rheumatology (ACR/Eular) 2010.

\subsubsection{Tatalaksana}

1. Pencegahan

Etiologi untuk penyakit RA ini belum diketahui secara pasti, namun berdasarkan penelitian-penelitian sebelumnya, ada beberapa hal yang dapat dilakukan untuk menekan faktor risiko :

a. Membiasakan berjemur di bawah sinar matahari pagi untuk mengurangi risiko peradangan oleh RA. Oleh penelitian Nurses Health Study AS yang menggunakan 1.314 wanita penderita RA didapatkan mengalami perbaikan klinis setelah rutin berjemur di bawah sinar UV-B.

b. Melakukan peregangan setiap pagi untuk memperkuat otot sendi. Gerakangerakan yang dapat dilakukan antara lain, jongkok-bangun, menarik kaki ke belakang pantat, ataupun gerakan untuk melatih otot lainnya. Bila mungkin, aerobik juga dapat dilakukan atau senam taichi.

c. Menjaga berat badan. Jika orang semakin gemuk, lutut akan bekerja lebih berat untuk menyangga tubuh. Mengontrol berat badan dengan diet makanan dan olahraga dapat mengurang risiko terjadinya radang pada sendi.

d. Mengonsumsi makanan kaya kalsium seperti almond, kacang polong, jeruk, bayam, buncis, sarden, yoghurt, dan susu skim. Selain itu vitamin A,C, D, E 
juga sebagai antioksidan yang mampu mencegah inflamasi akibat radikal bebas.

e. Memenuhi kebutuhan air tubuh. Cairan synovial atau cairan pelumas pada sendi juga terdiri dari air. Dengan demikian diharapkan mengkonsumsi air dalam jumlah yang cukup dapat memaksimalkan sistem bantalan sendi yang melumasi antar sendi, sehingga gesekan bisa terhindarkan. Konsumsi air yang disrankan adalah 8 gelas setiap hari (Candra, 2013).

f. Berdasarkan sejumlah penelitian sebelumnya, ditemukan bahwa merokok merupakan faktor risiko terjadinya RA. Sehingga salah satu upaya pencegahan RA yang bisa dilakukan masyarakat ialah tidak menjadi perokok akif maupun pasif (Febriana, 2015).

\subsection{Konsep Ansietas}

\subsubsection{Defenisi}

Kecemasan merupakan suatu keadaan perasaan gelisah, ketidaktentuan, ada rasa takut dari kenyataan atau persepsi ancaman sumber aktual yang tidak diketahui masalahnya (Pardede \& Simangunsong, 2020). Kecemasan merupakan suatu respon psikologis maupun fisiologis individu terhadap suatu keadaan yang tidak menyenangkan, atau reaksi atas situasi yang dianggap mengancam (Hulu \& Pardede, 2016).

Kecemasan (anxiety) merupakan perasaantakut yang tidak jelas penyebabnya dan tidak didukung oleh situasi yang ada. Kecemasan dapat dirasakan oleh setiap orang jika mengalami tekanan dan perasaan mendalam yang menyebabkan masalah psikiatrik dan dapat berkembang dalam jangka waktu lama. (Marbun, Pardede \& Perkasa, 2019). Kecemasan yang terjadi tidak saja dialami oleh seorang pasien tetapi dapat juga dialami oleh perawat karena perawat terkadang cemas ketika berhadapan dengan pasien dan keluarga pasien (Pardede, Keliat, Damanik, \& Gulo, 2020).

Kecemasan adalah pengalaman subjektif dari ketegangan mental yang mengganggu sebagai reaksi umum dan ketidakmampuan untuk menghadapi masalah atau adanya rasa tidak aman. Perasaan tidak menyenangkan umumnya menimbulkan gejala fisiologis (seperti gemetar, berkeringat, detak jantung meningkat, dll) dan gejala 
psikologis seperti panik, tegang, bingung, tidak dapat berkonsentrasi, dll ( Pardede, Simanjuntak, \& Manalu 2020).

Dampak dari kecemasan berat pada pasien preoperasi tidak menutup kemungkinan tindakan pembedahan tidak bisa dilakukan, karena pasien yang cemas sebelum dilakukan operasi akan menyebabkan tekanan darah meningkat, sehingga ketika dilakukan tindakan pembedahan akan mempersulit dalam menghentikan perdarahan, dan bahkan setelah tindakan pembedahan pun akan menghambat penyembuhan (Pardede, Hulu \& Sirait, 2021).

\subsubsection{Etiologi}

Meski penyebab ansietas belum sepenuhnya diketahui, namun gangguan keseimbangan neurotransmitter dalam otak dapat menimbulkan ansietas pada diri seseorang.

Faktor genetik juga merupakan faktor yang dapat juga menimbulkan gangguan ini, ansietas terjadi ketika seseorang mengalami kesulitan menghadapi situa si, masalah dan tujuan hidup (Videbeck, 2018).

Setiap individu menghadapi stress dengan cara berbeda-beda, seseorang dapat tumbuh dalam situasi yang dapa menimbulkan stress berat pada orang lain adapun faktorfaktornya yang mempengaruhi ansietas adalah :

\section{Faktor predisposisi}

Berbagai teori yang dikembangkan untuk menjelaskan penyebab ansietas adalah :

a. Teori psikionalitik

Ansietas merupakan konflik emosional antara dua elemen yaitu ide, ego dan super ego. Ide melambangkan dorongan insting, ego digambarkan sebagai mediator antara ide dan super ego mencerminkan hati nurani seseorang dan dikendalikan oleh norma-norma budaya seseorang, ansietas berfungsi untuk memperingatkan ego tenang suatu budaya yang perlu segera diatasi.

b. Teori interpersonal

Ansietas terjadi dari ketakutan akan penolakan interpersonal berhubungan juga dengan trauma masa perkembangan seperti kehilangan, 
perpisahan. Individu dengan harga diri rendah biasanya sangat mengalami ansietas berat.

c. Teori perilaku

Ansietas merupakan produk frustasi yaitu segala sesuatu yang yang menggangu kemampuan seseorang untuk mencapai tujuan yang diharapkan.

d. Kajian biologis

Kajian biologis menunjukan bahwa otak mengandung reseptor khusus untuk benzodiazepin, obat-obatan yang meningkatan neuroregulator yang berperan penting dalam mekanisme biologis yang berhubungan dengan ansietas (Stuart, Keliat \& Pasaribu, 2016).

2. Faktor presipitasi

Bersumber dari eksternal dan internal seperti :

a. Ancaman terhadap integritas fisik meliputi ketidakmampuan fisiologis atau menurunnya kemampuan melaksanakan fungsi kehidpan sehari-hari (Stuart, Keliat \& Pasaribu, 2016)

b. Ancaman terhadap sistem diri dapat membahayakan identitas harga diri dan integritas fungsi sosial (Stuart, Keliat \& Pasaribu, 2016).

3. Perilaku

Ansietas dapat diekspresikan langsung melalui perubahan fisiologis dan perilaku secara tidak langsung timbulnya gejala atau mekanisme koping dalam meningkat sejalan dengan peningkatan ansietas.

\subsubsection{Tingkat Ansietas}

1. Ansietas Ringan

Ansietas ringan berhubungan dengan ketegangan akan peristiwa kehidupan seharihari. Pada tingkat ini lapangan persepsi melebar dan individu terdorong untuk belajar yang akan menghasilkan pertumbuhan kreatifitas (Bulechek, 2016).

a. Respon fisiologis

1) Sesekali napas pendek

2) Nadi dan tekanan darah naik

3) Gejala ringan pada lambung

4) Muka berkerut dan bibir bergetar 


\section{b. Respon kognitif}

1) Lapang persepsi melebar

2) Mampu menerima rangsangan yang kompleks

3) Konsentrasi pada maslah

4) Menejlaskan masalah secara efektif

c. Respon perilaku dan emosi
1) Tidak dapat duduk tenang
2) Tremor halus pada tangan
3) Suara kadang-kadang meninggi

2. Ansietas sedang

Pada tingkat ini lapangan persepsi terhadap lingkugan menurun. Individu lebih memfokuskan hal-hal penting dan mengenyampingkan hal-hal lain (Bulechek, 2016).

a. Respon fisiologis

1) Nadi (ekstra systole) dan tekanan darah naik

2) Mulut kering

3) Anorexia

4) Diare/konstipasi

5) Gelisah

b. Respon kognitif

1) Lapang persepsi menyempit

2) Rangsang luar tidak mampu diterima

3) Berfokus pada apa yang menjadi perhatian

c. Respon perilaku dan emosi

1) Gerakan tersentak-sentak (meremas tangan)

2) Bicara banyak dan lebih cepat

3) Susah tidur

4) Perasaan tidak aman

3. Ansietas berat

Pada ansietas berat lapangan persepsi menjadi sangat sempit, individu cenderung memikirkan hal yang kecil saja dan mengabaikan hal lain,individu tidak mampu 
lagi berpikir realistis dan membutuhkan pengarahan untuk memusatkan perhatian pada area lain (Bulechek, 2016).

a. Respon fisiologi

1) Sering nafas pendek Nadi dan tekanan darah naik

2) Berkeringat dan sakit kepala

3) Penglihatan kabur

4) Ketegangan

b. Respon kognif

1) Lapang persepsi sangat sempit

2) Tidak mampu menyelesaikan masalah

3) Respon perilaku dan emosi

4) Perasaan ancam meningkat

5) verbialisasi cepat

6) Blocking

\subsubsection{Mekanisme Koping}

Ketika pasien mengalami ansietas, individu menggunakan bermacam-macam mekanisme koping untuk mencoba mengatasinya. Dalam bentuk ringan ansietas bentuk ringan ansietas dapat di atasi dengan menangis, tertawa, tidur, olahraga atau merokok.

Bila terjadi ansietas berat sampai panik akan terjadi ketidakmampuan mengatasi ansietas secara konstruktif merupakan penyebab utama perilaku yang patologis, individu akan menggunakan energy yang lebih besar untuk dapat mengatasi ancaman tersebut.

Mekanisme koping untuk mengatasi ansietas adalah :

2. Reaksi yang berorientasi pada tugas (task oriented reaction) Merupakan pemecahan masalah secara sadar yang digunakan untuk menanggulangi ancaman stressor yang ada secara realistis yaitu :

a. Perilaku menyerang (Agresif) Biasanya digunakan individu untuk mengatasi rintangan agar memenuhi kebutuhan.

b. Perilaku menarik diri Digunakan untuk menghilangkan sumber ancaman baik secara fisik maupun psikologis.

c. Perilaku kompromi Digunakan untuk merubah tujuan yang akan dilakukan atau mengorbankan kebutuhan personal untuk mencapai tujuan. 
3. Mekanisme pertahanan ego (Ego oriented reaction) Mekanisme ini membantu mengatasi ansietas ringan dan sedang yang digunakan untuk melindungi diri dan dilakukan secara sadar untuk mempertahankan keseimbangan.

Mekanisme pertahanan ego :

a. Disosiasi adalah pemisahan dari proses mental atau perilaku dari kesadaran atau identitasnya.

b. Identifikasi (identification) adalah proses dimana seseorang untuk menjadi yang ia kagumi berupaya dengan mengambil/meniru pikiran-pikiran, perilaku dan selera orang tersebut.

c. Intelektualisasi (intellectualization) adalah penggunaan logika dan alasan yang berlebihan untuk menghindari pengalaman yang mengganggu perasaannya.

d. Introjeksin (introjection) adalah suatu jenis identifikasi yang dimana seseorang mengambil dan melebur nilai-nilai dan kualitas seseorang atau suatu kelompok kedalam struktur egonya sendiri, berupa hati nurani, contohnya rasa benci atau kecewa terhadap kematian orang yang dicintai, dialihkan dengan cara menyalahkan diri sendiri.

e. Kompensasi adalah proses dimana seseorang memperbaiki penurunan citra diri dengan secara tegas menonjolkan keistimewaan/kelebihan yang dimilikinya. Penyangkalan (Denial) adalah menyatakan ketidaksetujuan terhadap realitas dengan mengingkari realitas tersebut. Mekanisme pertahanan ini adalah penting, sederhana, primitif.

f. Pemindahan (displacement) adalah pengalihan emosi yang semula ditujukan pada seseorang/benda kepada orang lain/benda lain yang biasanya netral atau kurang mengancam dirinya.

g. Isolasi adalah pemisahan unsur emosional dari suatu pikiran yang menggangu dapat bersifat sementara atau berjangka lama.

h. Proyeksi adalah pengalihan buah pikiran atau impuls pada diri sendiri kepada orang lain terutama keinginan, perasaan emosional dan motivasi yang tidak dapat ditoleransi.

i. Rasionalisasi adalah mengemukakan penjelasan yang tampak logis dan dapat diterima masyarakat untuk membenarkan perasaan perilaku dan motif yang tidak dapat diterima. 
j. Reaksi formasi adalah pengembangan sikap dan pola perilaku yang ia sadari yang bertentangan dengan apa yang sebenarnya ia rasakan atau ingin dilakukan.

k. Regresi adalah kemunduran akibat stress terhadap perilaku dan merupakan ciri khas dari suatu taraf perkembangan yang lebih dini.

1. Represi adalah pengenyampingkan secara tidak sadar tentang-tentang pikiran, ingatan yang menyakitkan atau bertentangan, dari kesadaran seseorang merupakan pertahanan ego yang primer yang cenderung diperkuat oleh mekanisme lain.

\subsection{Konsep Asuhan Keperawatan}

\subsubsection{Pengkajian}

\section{Faktor Predisposisi}

Berbagai teori telah dikembangkan untuk menjelaskan asal ansietas Stuart, Keliat \& Pasaribu (2016) :

a. Teori Psikoanalitik

Ansietas adalah konflik emosional yang terjadi antara dua elemen kepribadian, ID dan superego. ID mewakili dorongan insting dan impuls primitif seseorang, sedangkan superego mencerminkan hati nurani seseorang dan dikendalikan oleh norma- norma budaya seseorang. Ego atau Aku, berfungsi menengahi hambatan dari dua elemen yang bertentangan dan fungsi ansietas adalah mengingatkan ego bahwa ada bahaya.

b. Teori Interpersonal

Ansietas timbul dari perasaan takut terhadap tidak adanya penerimaan dari hubungan interpersonal. Ansietas juga berhubungan dengan perkembangan, trauma seperti perpisahan dan kehilangan sehingga menimbulkan kelemahan spesifik. Orang dengan harga diri rendah mudah mengalami perkembangan ansietas yang berat.

c. Teori Perilaku

Ansietas merupakan produk frustasi yaitu segala sesuatu yang mengganggu kemampuan seseorang untuk mencapai tujuan yang diinginkan.Daftar tentang pembelajaran meyakini bahwa individu yang terbiasa dalam kehidupan dininya dihadapkan pada ketakutan yng berlebihan lebih sering menunjukkan ansietas pada kehidupan selanjutnya. 


\section{d. Kajian Keluarga}

Menunjukkan bahwa gangguan ansietas merupakan hal yang biasa ditemui dalam suatu keluarga.Ada tumpang tindih dalam gangguan ansietas dan antara gangguan ansietas dengan depresi.

e. Kajian Biologis

Menunjukkan bahwa otak mengandung reseptor khusus benzodiazepine. Reseptor ini mungkin membantu mengatur ansietas penghambat dalam aminobutirik. Gamma neuroregulator (GABA) juga mungkin memainkan peran utama dalam mekanisme biologis berhubungan dengan ansietas sebagaimana halnya endorfin. Selain itu telah dibuktikan kesehatan umum seseorang mempunyai akibat nyata sebagai predisposisi terhadap ansietas. Ansietas mungkin disertai dengan gangguan fisik dan selanjutnya menurunkan kapasitas seseorang untuk mengatasi stressor.

\section{Faktor Presipitasi}

Stressor pencetus mungkin berasal dari sumber internal atau eksternal. Stressor pencetus dapat dikelompokkan menjadi 2 kategori :

a. Ancaman terhadap integritas seseorang meliputi ketidakmampuan fisiologis yang akan datang atau menurunnya kapasitas untuk melakukan aktifitas hidup seharihari.

b. Ancaman terhadap sistem diri seseorang dapat membahayakan identitas, harga diri dan fungsi sosial yang terintegrasi seseorang.

3. Perilaku

Kecemasan dapat diekspresikan secara langsung melalui perubahan fisiologi dan perilaku dan secara tidak langsung melalui timbulnya gejala atau mekanisme koping dalam upaya melawan kecemasan. Intensitas perilaku akan meningkat sejalan dengan peningkatan tingkat kecemasan.

a. Respon Fisiologis Terhadap Ansietas

\section{Sistem Tubuh Respons}


Kardiovaskuler

\section{Palpitasi.}

Jantung berdebar.

Tekanan darah meningkat dan denyut nadi menurun.

Rasa mau pingsan dan pada akhirnya pingsan.

Pernafasan

Napas cepat.

Pernapasan dangkal.

Rasa tertekan pada dada.

Pembengkakan pada tenggorokan.

- Rasa tercekik

- Terengah-engah.

Neuromuskular

- Peningkatan reflek

- Reaksi kejutan

- Insomnia

- Ketakutan

- Gelisah

- Wajah tegang

- Kelemahan secara umum.

- Gerakan lambat

- Gerakan yang janggal

Gastrointestina

1

$\square$ Kehilangan nafsu makan.

$\square$ Menolak makan.

Perasaan dangkal.

Rasa tidak nyaman pada abdomina

Rasa terbakar pada jantung. 
Nausea.

Diare.

Perkemihan

- Tidak dapat menahan kencing.

- Sering kencing.

Kulit

- Rasa terbakar pada mukosa.

- Berkeringat banyak pada telapak tangan

- Gatal-gatal.

- Perasaan panas atau dingin pada kulit.

- Muka pucat dan bekeringat diseluruh tubuh.

b. Respon Perilaku Kognitif

$\begin{array}{ll}\text { Sistem } & \text { Respons } \\ \text { Perilaku } & \\ & \square \text { Gelisah. } \\ & \square \text { Ketegangan fisik. } \\ & \square \text { Tremor. } \\ & \square \text { Gugup. } \\ & \square \text { Bicara cepat. } \\ & \square \text { Tidak ada koordinasi. } \\ & \square \text { Kecenderungan untuk celaka. } \\ & \square \text { Menarik diri. } \\ & \square \text { Menghindar. }\end{array}$


$\square$ Terhambat melakukan aktifitas.

Kognitif

Gangguan perhatian.

Konsentrasi hilang.

Pelupa.

$\checkmark$ Salah tafsir.

Adanya bloking pada pikiran.

$\square$ Menurunnya lahan persepsi.

Kreatif dan produktif menurun.

Bingung.

Khawatir yang berlebihan.

Hilang menilai objektifitas.

Takut akan kehilangan kendali.

$\square$ Takut yang berlebihan.

Afektif

$\square$ Mudah terganggu.

$\square$ Tidak sabar.

$\square$ Gelisah.

$\square$ Tegang.

$\square$ Nerveus.

$\square$ Ketakutan.

4. Sumber Koping

Individu dapat mengalami stress dan ansietas dengan menggerakkan sumber koping tersebut di lingkungan. Sumber koping tersebut sebagai modal ekonomok, kemampuan penyelesaian masalah, dukungan sosial dan keyakinan budaya dapat 
membantu seseorang mengintegrasikan pengalaman yang menimbulkan stress dan mengadopsi strategi koping yang berhasil.

5. Mekanisme Koping

Ketika mengalami ansietas individu menggunakan berbagai mekanisme koping untuk mencoba mengatasinya dan ketidakmampuan mengatasi ansietas secara konstruktif merupakan penyebab utama terjadinya perilaku patologis. Ansietas tingkat ringan sering ditanggulangi tanpa yang serius.

Tingkat ansietas sedang dan berat menimbulkan 2 jenis mekanisme koping :

a. Reaksi yang berorientasi pada tugas, yaitu upaya yang disadari dan berorientasi pada tindakan untuk memenuhi secara realitis tuntutan situasi stress.

b. Mekanisme pertahanan ego, membantu mengatasi ansietas ringan dan sedang, tetapi jika berlangsung pada tingkat sadar dan melibatkan penipuan diri dan distorsi realitas, maka mekanisme ini dapat merupakan respon maladaptif terhadap stress.

\subsubsection{Diagnosa Keperawatan}

Adapun diagnosa yang biasanya muncul adalah Stuart, Keliat \& Pasaribu (2016) :

1. Koping Individu Tidak Efektif

2. Kecemasan

3. Ketidakberdayaan

4. Isolasi Sosial

5. Perubahan Proses Berfikir

\subsubsection{Intervensi Keperawatan}

1. Kecemasan

Tujuan :

- Klien mampu mengenal pengertian penyebab tanda gejala dan akibat

- Klien mampu mengetahui cara mengatasi ansietas

- Klien mampu mengatasi ansietas dengan melakukan latihan relaksasi tarik nafas dalam

- Klien mampu mengatasi ansietas dengan melakukan latihan distraksi

- Klien mampu mengatasi ansietas dengan melakukan hipnotis lima jari 
- Klien mampu merasakan manfaat dari latihan yang dilakukan

- Klien mampu membedakan perasaan sebelum dan sesudah latihan

Tindakan :

a. Kaji tanda dan gejala ansietas dan kemampuan klien mengurangi kecemasan

b. Jelaskan tanda dan gejala, penyebab dan akibat dari kecemasan

c. Latihan cara mengatasi kecemasan :

1) Teknik relaksasi napas dalam

2) Distraksi : bercakap-cakap hal positif

3) Hipnotis 5 jari fokus padahal-hal yang positif

d. Bantu klien melakukan latihan sesuai dengan jadwal kegiatan

2. Koping tidak efektif

Tujuan :

a. Klien mampu mengetahui perubahan kondisi kesehatan dan kemampuannya mengatasi perubahan.

b. Klien mampu mengetahui pengertian tanda dan gejala penyebab serta akibat dari ketidak efektifan koping

c. Klien mampu mengetahui cara mengatasi ketidak efektifan koping

d. Klien mampu mengatasi masalah secara bertahap

e. Klien mampu menggunakan sumber/daya sistem pendukung dalam mengatasi masalah

f. Klien mampu merasakan manfaat latihan yang dilakukan

g. Klien mampu mengembangkan koping yang efektif klien mampu merasakan manfaat sistem pendukung.

Tindakan :

a. Kaji tanda dan gejala ketidakefektifan koping

b. Jelaskan proses terjadinya ketidakefektifan koping

c. Diskusikan koping (upaya atau cara) mengatasi masalah pada masa lalu

d. Koping (upaya) yang berhasil dan tidak berhasil. Berikan pujian

e. Pemanfaatan sumber daya atau sistem pendukung dalam mengatasi masalah 
f. Latihan menggunakan upaya menyelesaikan masalah saat ini dengan menggunakan cara lama yang berhasil atau cara baru.

1. Buat daftar masalah yang dihadapi

2. Buat daftar cara (lama dan baru) yang akan digunakan

3. Pilih, latih, dan jadwalkan cara yang akan digunakan untuk masalah yang dihadapi

4. Evaluasi hasil jika berhasil dibudidayakan jika kurang berhasil dipilih cara lain pada daftar cara nomor kedua.

g. Latih menggunakan sistem pendukung yang teratur

h. Beri motivasi dan pujian atas keberhasilan klien mengatasi masalah

\subsubsection{Implementasi keperawatan}

Merupakan inisiatif dari rencana tindakan untuk mencapai tujuan yang spesifik. Tahap pelaksanaan dimulai dimulai setelah rencana tindakan disusun dan ditujukan pada nursing orders untuk membantu klien mencapai tujuan yang diharapkan. Oleh karena itu rencana tindakan yang spesifik dilaksanakan untuk memodifikasi faktorfaktor yang mempengaruhi masalah kesehatan klien (Stuart, Keliat \& Pasaribu, 2016).

Adapun tahap-tahap dalam tindakan keperawatan adalah sebagai berikut :

Tahap 1 : persiapan Tahap awal tindakan keperawatan ini menuntut perawat untuk mengevaluasi yang diindentifikasi pada tahap perencanaan.

Tahap 2 : intervensi Focus tahap pelaksanaan tindakan perawatan adalah kegiatan dan pelaksanaan tindakan dari perencanaan untuk memenuhi kebutuhan fisik dan emosional. Pendekatan tindakan keperawatan meliputi tindakan : independen,dependen, dan interdependen.

Tahap 3 : dokumentasi Pelaksanaan tindakan keperawatan harus diikuti oleh pencatatan yang lengkap dan akurat terhadap suatu kejadian dalam proses keperawatan.

\subsubsection{Evaluasi}

Perencanaan evaluasi memuat criteria keberhasilan proses dan keberhasilan tindakan keperawatan. Keberhasilan proses dapat dilihat dengan jalan membandingkan antara proses dengan pedoman/rencana proses tersebut. Sedangkan keberhasilan tindakan dapat dilihat dengan membandingkan antara tingkat kemandirian pasien dalam 
kehidupan sehari-hari dan tingkat kemajuan kesehatan pasien dengan tujuan yang telah di rumuskan sebelumnya.

Sasaran evaluasi adalah sebagai berikut :

1. Proses asuhan keperawatan, berdasarkan criteria/ rencana yang telah disusun.

2. Hasil tindakan keperawatan ,berdasarkan criteria keberhasilan yang telah di rumuskan dalam rencana evaluasi.

Hasil evaluasi Terdapat 3 kemungkinan hasil evaluasi yaitu :

1. Tujuan tercapai,apabila pasien telah menunjukan perbaikan/ kemajuan sesuai dengan criteria yang telah di tetapkan.

2. Tujuan tercapai sebagian,apabila tujuan itu tidak tercapai secara maksimal, sehingga perlu di cari penyebab dan cara mengatasinya.

3. Tujuan tidak tercapai,apabila pasien tidak menunjukan perubahan/kemajuan sama sekali bahkan timbul masalah baru.dalam hal ini perawat perlu untuk mengkaji secara lebih mendalam apakah terdapat data, analisis, diagnosa, tindakan, dan faktor-faktor lain yang tidak sesuai yang menjadi penyebab tidak tercapainya tujuan.

Setelah seorang perawat melakukan seluruh proses keperawatan dari pengkajian sampai dengan evaluasi kepada pasien,seluruh tindakannya harus di dokumentasikan dengan benar dalam dokumentasi keperawatan (Stuart, Keliat \& Pasaribu, 2016). 


\section{BAB 3}

TINJAUAN KASUS

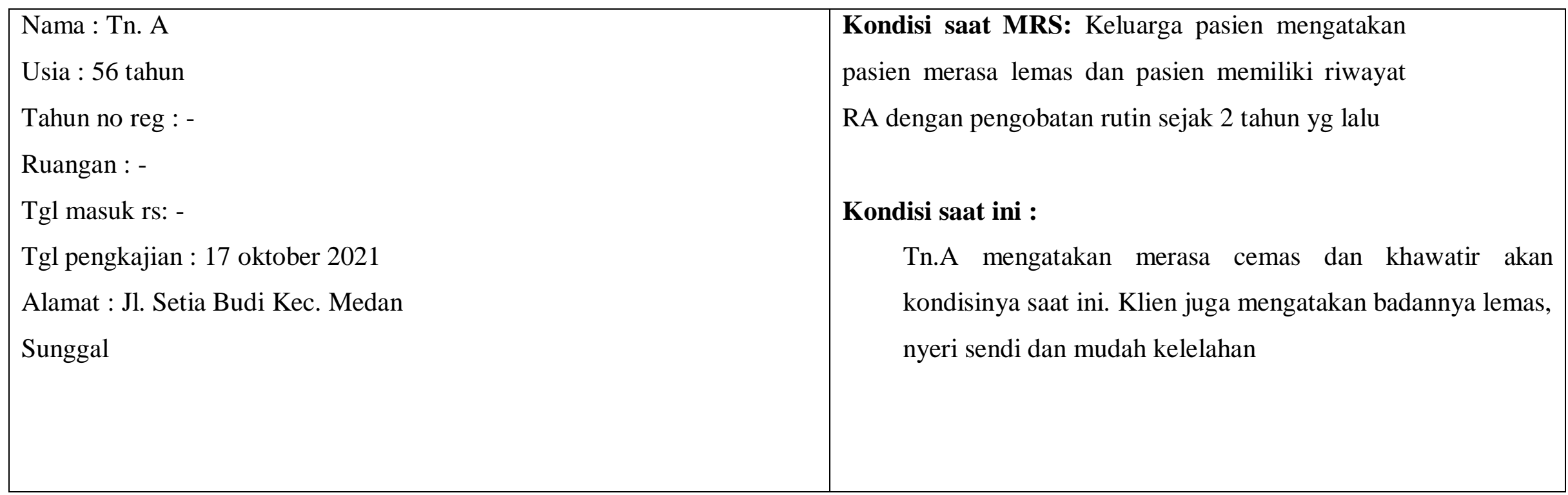


1. FAKTOR PREDISPOSISI DAN PRESIPITASI

\begin{tabular}{|c|c|c|c|c|}
\hline \multirow[t]{2}{*}{ FAKTOR PREDISPOSISI } & \multicolumn{3}{|c|}{ FAKTOR PRESIPITASI } & \multirow[t]{2}{*}{ STRESSOR } \\
\hline & Nature & Origin & $\begin{array}{c}\text { Number - } \\
\text { Timing }\end{array}$ & \\
\hline $\begin{array}{l}\text { 1. Klien memiliki riwayat RA } \\
\text { sejak } 2 \text { tahun yang lalu } \\
\text { 2. Tn. A selalu rutin check up } \\
\text { kepelayanan kesehatan } \\
\text { 3. Dalam keluarga tidak ada yg } \\
\text { menderita penyakit yang } \\
\text { sama dengan klien. }\end{array}$ & $\begin{array}{l}\text { - Nyeri sendi, } \\
\text { mudah } \\
\text { kelelahan, } \\
\text { kekakuan pada } \\
\text { sendi, mati rasa } \\
\text { dan kesemutan } \\
\text { - penurunan } \\
\text { jangkauan } \\
\text { gerak, demam, } \\
\text { kaku sendi di } \\
\text { pagi hari }\end{array}$ & Internal & Sejak terkena RA & - Rheumatoid Artritis \\
\hline \multirow[t]{2}{*}{ FAKTOR PREDISPOSISI } & \multicolumn{3}{|c|}{ FAKTOR PRESIPITASI } & \multirow[t]{2}{*}{ STRESSOR } \\
\hline & Nature & Origin & $\begin{array}{l}\text { Number - } \\
\text { Timing }\end{array}$ & \\
\hline $\begin{array}{l}\text { Psikologis : } \\
\begin{array}{l}\text { 1. Tn.A merasa gelisah dengan kondisi } \\
\text { penyakit nya dan keadaaan yang lemah } \\
\text { karna sudah menua } \\
\text { 2. Tn. A termasuk orang yang terbuka dan }\end{array}\end{array}$ & $\begin{array}{ll}\text { - } & \text { Gelisah, } \\
\text { jantung } \\
\text { berdebar } \\
\text { - } & \text { kepikiran } \\
\text { dengan } \\
\text { penyakitnya }\end{array}$ & Internal & $\begin{array}{c}\text { Sejak dilakukan } \\
\text { pengkajian }\end{array}$ & $\begin{array}{l}\text { - Ansietas } \\
\text { - Ketiak berdayaan } \\
\text { - Koping in Efektif }\end{array}$ \\
\hline
\end{tabular}




\begin{tabular}{|c|c|}
\hline $\begin{array}{l}\text { sering menceritakan } \\
\text { kesahnya kepada keluarga } \\
\text { 3. Tn.A merasa mati rasa, pening dan napas } \\
\text { pendek dan jantung terasa berdebar- } \\
\text { debar }\end{array}$ & $\begin{array}{l}\text { karena umur } \\
\text { semakin } \\
\text { menua } \\
\text { - merasa tidak } \\
\text { mampu } \\
\text { karna umur } \\
\text { semakin } \\
\text { menua }\end{array}$ \\
\hline $\begin{array}{l}\text { Sosiocultural } \\
\begin{array}{l}\text { 1. Tn.A berumur } 56 \text { tahun dan sudah } \\
\text { menikah dan memiliki } 5 \text { orang anak } \\
\text { 2. Tn.A merupakan seorang kepala } \\
\text { keluarga yang bekerja sebagai petani } \\
\text { 3. Tn.A beragama Kristen dan aktif } \\
\text { beribadah } \\
\text { 4. Tn.A rutin check up }\end{array}\end{array}$ & \\
\hline
\end{tabular}


GENOGRAM
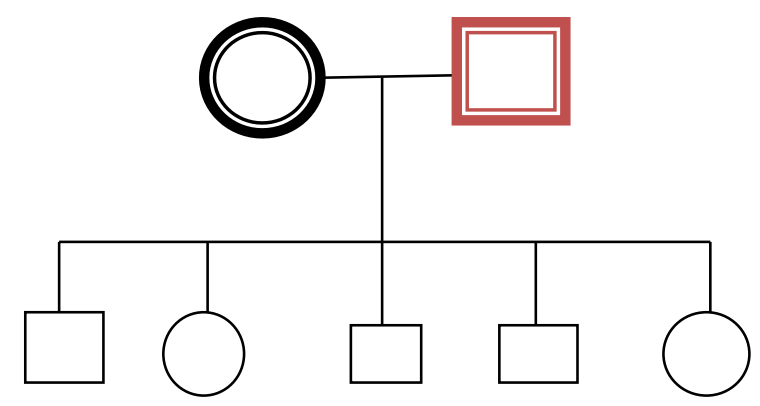

\section{Keterangan Genogram :}

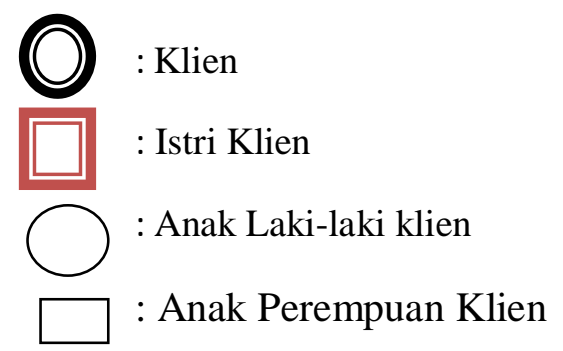

Pasien berumur 56 tahun, pasien sudah menikah dan memiliki 5 orang anak yaitu 3 perempuan dan 2 laki laki. Pasien tinggal serumah dengan anak terakhir dan istrinya. 
2. PENILAIAN TERHADAP STRESSOR

\begin{tabular}{|c|c|c|c|c|c|c|}
\hline TRESSOR & KOGNITIF & AFEKTIF & FISIOLOGIS & PERILAKU & SOSIAL & $\begin{array}{c}\text { DIAGNOSA } \\
\text { KEPERAWA } \\
\text { TAN } \\
\end{array}$ \\
\hline $\begin{array}{l}\text { cemas } \\
\text { dengan } \\
\text { keadaan } \\
\text { penyakit jika } \\
\text { semakin } \\
\text { parah atau } \\
\text { kambuh }\end{array}$ & $\begin{array}{l}\text { - Menurut Tn. A } \\
\text { penyakitnya } \\
\text { diakibat oleh pola } \\
\text { hidup yang tidak } \\
\text { baik } \\
\text { - Klien memikirkan } \\
\text { bagaiman jika } \\
\text { penyakiitnya } \\
\text { sewaktu waktu } \\
\text { kambuh }\end{array}$ & $\begin{array}{l}\text { - Tn.A } \\
\text { merasa } \\
\text { mulai } \\
\text { was was } \\
\text { dan } \\
\text { cemas } \\
\text { akan apa } \\
\text { yang } \\
\text { akan } \\
\text { terjadi } \\
\text { takut } \\
\text { karena } \\
\text { kondisi } \\
\text { penyakit } \\
\text { nya } \\
\text { semakin } \\
\text { buruk } \\
\text { dan juga } \\
\text { umurnya } \\
\text { yang } \\
\text { semakin } \\
\text { menua }\end{array}$ & \begin{tabular}{|l} 
- TD turun \\
- Banyak \\
berkeringat \\
- Nyeri sendi \\
- demam \\
- kelelahan \\
- kekakuan pada \\
sendi \\
- kaku sendi \\
dipagi hari \\
- penurunan \\
jangkauan gerak \\
- Pemeriksaan \\
TTV \\
TD: $130 / 80$ \\
mmHg \\
$\mathrm{N}: 89$ x / \\
menit \\
P : $22 \quad$ x / \\
menit \\
S: $38{ }^{0} \mathrm{C}$ \\
Nyeri yang dialami \\
pasien yaitu nyeri \\
berat.
\end{tabular} & $\begin{array}{l}\text { - } \text { Tn.A merasa } \\
\text { nyeri sendi dan } \\
\text { kaku sendi. } \\
\text { - } \text { Tn.A tampak } \\
\text { gelisah dan } \\
\text { khawatir }\end{array}$ & $\begin{array}{l}\text { Klien } \\
\text { memanfaatkan } \\
\text { fasilitas yang ada } \\
\text { untuk pengobatan } \\
\text { penyakitnya. }\end{array}$ & - Ansietas \\
\hline
\end{tabular}




\begin{tabular}{|c|c|c|c|c|c|c|}
\hline $\begin{array}{c}\text { STRESSO } \\
\mathbf{R}\end{array}$ & KOGNITIF & AFEKTIF & FISIOLOGIS & PERILAKU & SOSIAL & $\begin{array}{c}\text { DIAGNOSA } \\
\text { KEPERAWA } \\
\text { TAN } \\
\end{array}$ \\
\hline $\begin{array}{l}\text { Ketidak } \\
\text { mampuan } \\
\text { fisik untuk } \\
\text { melakukan } \\
\text { aktiviatas } \\
\text { berat }\end{array}$ & $\begin{array}{l}\text { - Klien memikirkan } \\
\text { umur yang menua } \\
\text { dan berpenyakit } \\
\text { membuat dia } \\
\text { Semakin lemah } \\
\text { sehingga tidak bisa } \\
\text { melakukan hal-hal } \\
\text { berat. }\end{array}$ & $\begin{array}{l}\text { - Merasa } \\
\text { khawatir } \\
\text { dan sedih } \\
\text { kepada } \\
\text { istrinya } \\
\text { yang juga } \\
\text { sudah } \\
\text { menua dan } \\
\text { sakit- } \\
\text { sakitan } \\
\text { - Merasa } \\
\text { bingung } \\
\text { dan } \\
\text { tidak tau } \\
\text { mau } \\
\text { berbuat } \\
\text { apa } \\
\text { dengan } \\
\text { keadaan } \\
\text { sekarang }\end{array}$ & $\begin{array}{l}\text { - Tampak lemas } \\
\text { - tampak lesu } \\
\text { dan kusam } \\
\text { - tengkuk dan } \\
\text { Bahu terasa } \\
\text { tegang } \\
\text { - Tn.A tampak } \\
\text { mukosam bibir } \\
\text { kering } \\
\text { - Nafas pendek } \\
\text { - TD 180/90 } \\
\text { mmhg } \\
\text { - RR 25x/, } \\
\text { - HR 95x/, }\end{array}$ & $\begin{array}{l}\text { - Perasaan tidak } \\
\text { mampu } \\
\text { - Tampak } \\
\text { gelisah }\end{array}$ & $\begin{array}{l}\text { - Hubungan } \\
\text { Tn.A dengan } \\
\text { istri baik } \\
\text { - Hubungan } \\
\text { Tn.A dengan } \\
\text { anak- anaknya } \\
\text { baik } \\
\text { - Tn.A tetap } \\
\text { rutin } \\
\text { program } \\
\text { pengobatan }\end{array}$ & 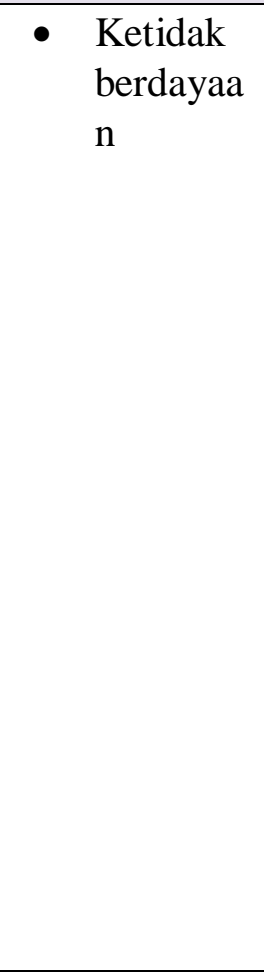 \\
\hline $\begin{array}{c}\text { STRESSO } \\
\text { R }\end{array}$ & KOGNITIF & AFEKTIF & FISIOLOGIS & PERILAKU & SOSIAL & $\begin{array}{c}\text { DIAGNOSA } \\
\text { KEPERAWA } \\
\text { TAN } \\
\end{array}$ \\
\hline $\begin{array}{l}\text { Merasa } \\
\text { tidak } \\
\text { mampu } \\
\text { karna umur } \\
\text { yang menua } \\
\text { kekuatan }\end{array}$ & $\begin{array}{l}\text { Klien memikirkan } \\
\text { bagaiaman ia merawat } \\
\text { istrinya }\end{array}$ & $\begin{array}{l}\text { - Merasa } \\
\text { khawatir } \\
\text { dan sedih } \\
\text { juga sudah } \\
\text { menua dan } \\
\text { sakit- }\end{array}$ & $\begin{array}{l}\text { - Tampak lemas } \\
\text { - Nyeri sendi, } \\
\text { wajah tampak } \\
\text { lesu dan kusam, } \\
\text { nafas pendek }\end{array}$ & 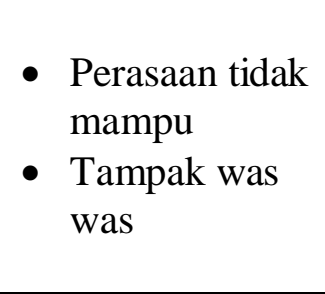 & $\begin{array}{ll}\text { - Hubungan } \\
\text { Tn.A dengan } \\
\text { istri baik } \\
\text { - hubungan Tn.A } \\
\text { dengan anak- } \\
\text { anaknya baik }\end{array}$ & $\begin{array}{l}\text { Koping } \\
\text { Individu } \\
\text { tidak } \\
\text { Efektif }\end{array}$ \\
\hline
\end{tabular}




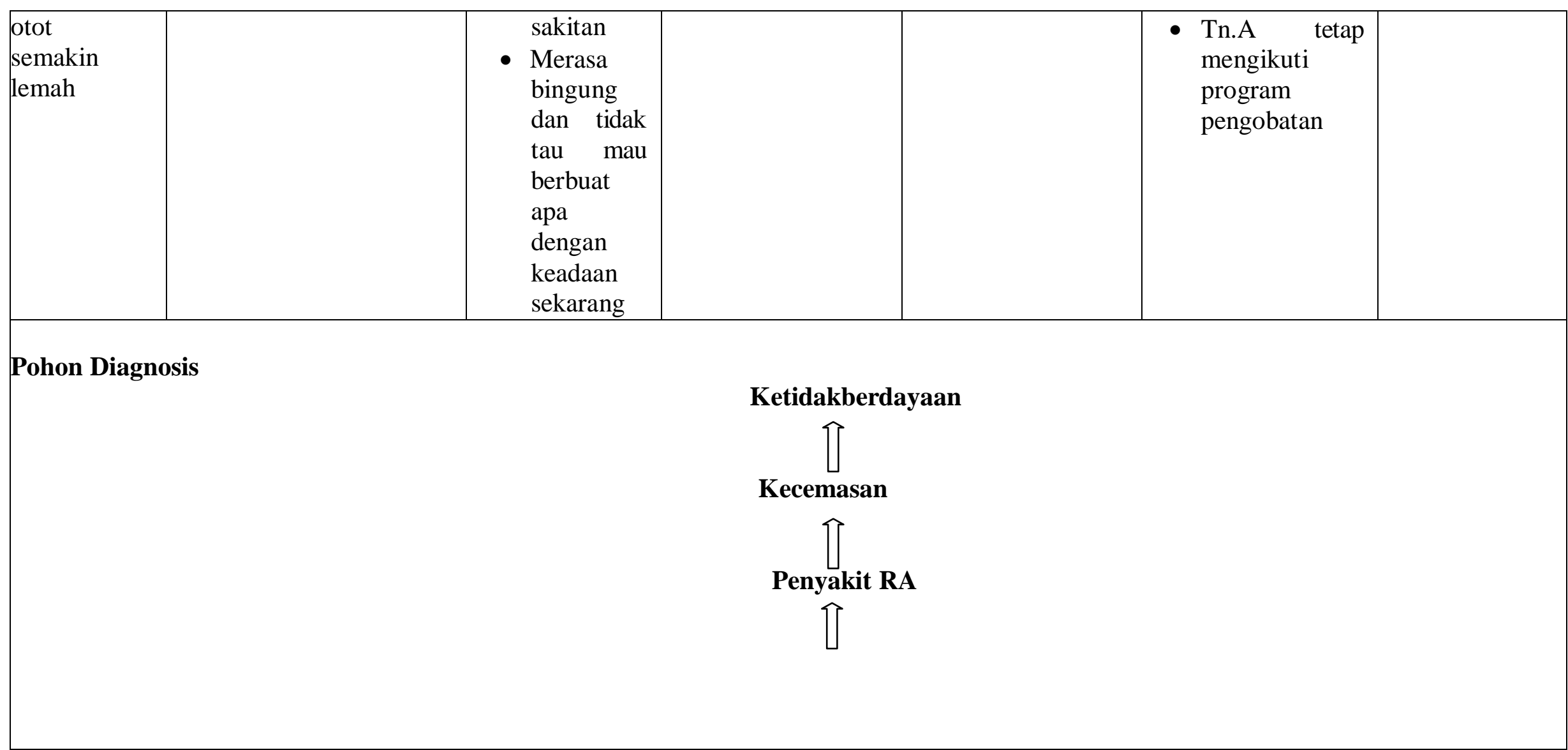


1. SUMBER KOPING

\begin{tabular}{|c|c|c|c|c|c|}
\hline $\begin{array}{c}\text { DIAGNOSA } \\
\text { KEPERAWATAN }\end{array}$ & PERSONAL ABILITY & SOSIAL SUPPORT & $\begin{array}{l}\text { MATERIAL } \\
\text { ASSET }\end{array}$ & BELIEF & TERAPI \\
\hline Ansietas & $\begin{array}{l}\text { - pasien tidak mampu } \\
\text { melakukan perkerjaan }\end{array}$ & - istri dan anak anak & - dana pribadi & 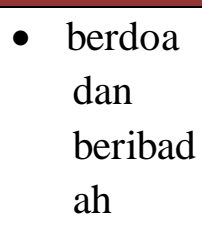 & $\begin{array}{l}\text { Terapi } \\
\text { spesialis: } \\
\text { - Relaksasi } \\
\text { distraksi }\end{array}$ \\
\hline Ketidakberdayaan & - Klien sudah mulai tidak kuat & - Istri dan Anak anak & - dana pribadi & $\begin{array}{l}\text { berdoa } \\
\text { dan } \\
\text { beribad } \\
\text { ah }\end{array}$ & $\begin{array}{l}\text { Mediskusikan } \\
\text { ketidak } \\
\text { berdayaan } \\
\text { yang } \\
\text { dirasakan } \\
\text { pasien/latihan } \\
\text { berpikir } \\
\text { positif }\end{array}$ \\
\hline $\begin{array}{l}\text { Koping individu } \\
\text { tidak efektif }\end{array}$ & - klien menyemangati diri sendiri & - Istri dan anak anak & - dana pribadi & 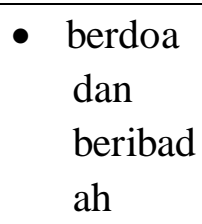 & $\begin{array}{l}\text { Terapi } \\
\text { Perilaku }\end{array}$ \\
\hline
\end{tabular}

\section{MEKANISME KOPING}

\begin{tabular}{|c|c|c|}
\hline \multirow{2}{*}{ UPAYA YANG DILAKUKAN } & \multicolumn{2}{|c|}{ ANALISA/KESAN } \\
\cline { 2 - 3 } - klien menceritakan bila ada masalah, maka ia akan membicarakan dengan istri & KONSTRUKTIF & DESTRUKTIF \\
\hline
\end{tabular}


dan anaknnya untuk mencari jalan keluarnya

- Bila sakit klien berobat ke pelayanan kesehatan

- klien taat menjalankan ibadah sesuai dengan keyakinannya

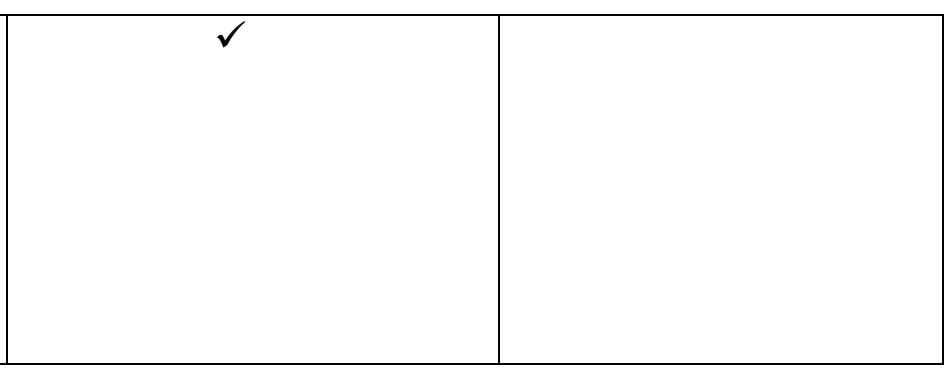

3. STATUS MENTAL

\begin{tabular}{|l|l|}
\hline 1. Penampilan & Rapi dan bersih \\
\hline 2. Pembicaraan & Klien berbicara dengan jelas tetapi sekali menarik napas panjang \\
\hline 3. Aktivitas motorik & Klien tampak sedikit tenang tetapi jika membicarakan penyakit klien lemas, cemas dan malu \\
\hline 4. Interaksi selama wawancara & Klien mau menjawab pertanyaan yg diberikan, kontak mata tidak fokus \\
\hline 5. Alam perasaan & Menunjukan ekpresi khawatir dan cemas, tidk mampu \\
\hline 6. Afek & Sesuai dengan stimulus yg diberikan \\
\hline 7. Persepsi & Tidak pernah mengalami halusinasi \\
\hline 8. Isi pikir & Normal \\
\hline 9. Proses pikir & Normal \\
\hline 10. Tingkat kesadaran & Normal \\
\hline 11. Daya ingat & Baik \\
\hline 12. Kemampuan berhitung & Baik \\
\hline 13. Penilaian & Klien mampu memberikan keputusan ketika merasa sakit \\
\hline 14. Daya tilik diri & Klien sedkit tidak mengeri dengan penyakitnya \\
\hline
\end{tabular}




\section{DIAGNOSA DAN TERAPI}

\begin{tabular}{|c|c|}
\hline $\begin{array}{l}\text { DIAGNOSA KEPERAWATAN DAN TERAPI } \\
\text { KEPERAWATAN }\end{array}$ & $\begin{array}{l}\text { DIAGNOSA MEDIS DAN TERAPI } \\
\text { MEDIS }\end{array}$ \\
\hline $\begin{array}{l}\text { 1. Ansietas } \\
\text { Sp1: mendiskusikan penyebab,terjadinya } \\
\text { prosesterjadi, tanda gejala,akibat } \\
\text { Sp2 : melatih teknik releksasi fisik } \\
\text { Sp3 : melatih mengatasi ansietas } \\
\text { dengan distraksi dan hipnotis lima } \\
\text { Sp4 : melatih mengatasi ansietas memalui } \\
\text { kegiatan spiritual } \\
\text { 2. Ketidakberdayaan } \\
\text { Sp1. Assement ketidakerdayaan dan } \\
\text { latihan berpikir positif } \\
\text { Sp2. Manfaat mengembangkan harapan } \\
\text { positif dan latihan mengontrol perasaan } \\
\text { 3. Koping Individu Tidak Efektif } \\
\text { Terapi Perilaku }\end{array}$ & $\begin{array}{l}\text { RA } \\
\text { Terapi } \\
\text { 1. Simplisia jahe untuk penurunan nyeri Rheumatoid Arthritis } \\
\text { 2. Kompres hangat jahe terhadap intensitas nyeri RA } \\
\text { 3. Kompres air hangat }\end{array}$ \\
\hline
\end{tabular}




\begin{tabular}{|c|c|}
\hline IMPLEMENTASI TINDAKAN KEPERAWATAN & EVALUASI SOAP \\
\hline $\begin{array}{l}\text { Tanggal : } 18 \text { Oktober } 2021 \\
\text { Jam : } 11.00 \text { wib } \\
\text { e. Kaji tanda dan gejala ansietas dan kemampuan klien mengurangi kecemasan } \\
\text { f. Jelaskan tanda dan gejala, penyebab dan akibat dari kecemasan } \\
\text { g. Latihan cara mengatasi kecemasan : } \\
\text { 4) Teknik relaksasi napas dalam } \\
\text { 5) Distraksi : bercakap-cakap hal positif } \\
\text { 6) Hipnotis } 5 \text { jari fokus padahal-hal yang positif } \\
\text { h. Bantu klien melakukan latihan sesuai dengan jadwal kegiatan. }\end{array}$ & $\begin{array}{ll}\text { S : } & \text { Klien mengatakan : merasa lebih tenang tetapi } \\
& \text { belum sepenuhnya cemasnya hilang } \\
\text { - } & \text { Klien mengatakan ia mampu mengindentifikasi } \\
& \text { situasi yang mencetus ansietas } \\
\text { O : } & \\
\text { - } & \text { Klien tampak rileks dan tidak gelisah lagi } \\
\text { - } & \text { Klen mampu menjelaskan kembali penjelasan } \\
& \text { yang sudah diberikan } \\
\text { A : } & \text { Ansietas (+) } \\
\text { P : } \quad & \\
\text { - } \quad \text { Evaluasi SP-1 dan SP-2 } \\
\text { - Latihan cara mengatasi kecemasan : } \\
\text { - Teknik relaksasi napas dalam } \\
\text { - Distraksi : bercakap-cakap hal positif } \\
\text { - Hipnotis } 5 \text { jari fokus padahal-hal yang positif } \\
\text { - } \quad \text { Bantu klien melakukan latihan sesuai dengan } \\
\text { jadwal kegiatan }\end{array}$ \\
\hline
\end{tabular}


Tanggal : 19 Oktober 2021

Jam : $11.00 \mathrm{wib}$

a. Latihan cara mengatasi kecemasan :

- Teknik relaksasi napas dalam

- Distraksi : bercakap-cakap hal positif

- Hipnotis 5 jari fokus padahal-hal yang positif

b. Bantu klien melakukan latihan sesuai dengan jadwal kegiatan.
S :

- Klien mengatakan : merasa lebih tenang dan tidak merasa cemas lagi

- Klien mengatakan ia mampu mengindentifikasi situasi yang mencetus ansietas

- Klien mengatakan sudah bisa melakukan teknik tarik napas dalam

- Klien mengatakan sudah bisa melakukan teknik distraksi

- Klien mengatakan sudah bisa melakukan teknik hipnotis 5 jari

O :

- Klien tampak rileks dan tidak gelisah lagi

- Klen mampu menjelaskan kembali penjelasan yang sudah diberikan

- Klien mampu melakukan teknik napas dalam

- Klien mampu melakukan distraksi

- Klien mampu melakukan hipnotis 5 jari

A : Ansietas (-)

P :

- Bantu klien melakukan latihan sesuai dengan jadwal kegiatan

- Terapi Perilaku

- Terapi Kognitif

- pendidkan kesehatan 


\section{Tanggal: 20 Oktober 2021}

Jam: 11.00 wib

1. Melakukan salam teraupetik

2. Menanyakan kepada klien faktor penyebab penyakit

3. Menanyakan kepada klien mengapa merasa cemas dan tidak berdaya

4. Mengajarkan cara relaksasi untuk mengurangi kecemasan

5. Mengajarkan klien latihan berpikir positif

6. mendiskusikan ketidakberdayaan yang dialami pasien

\section{S: -Klien mengatakan kecemasan berkurang}

Klien mengatakan perasaan tidak berdaya semakin

berkurang dan akan berpikir positif

O : - Klien tampak tenang saat mengungkapkan perasaanyan dan selalau melakukan terapi tarik napas dalam

- Klien menceritakan ketidak berdayaannya, penyebab dll.

\section{A : Ketidakberdayaan (+) / tujuan tercapai}

$\mathbf{P}_{\text {Klien : Klien melakukan terapi dirumah }}$

$\mathbf{P}_{\text {perawat }}$ : Evaluasi terapi satu tercapai. melanjutkan terapi kedua 


\section{Tanggal: 21 Oktober 2021}

Jam: 13.00 wib

1. Melakukan salam teraupetik

2. Menanyakan kepada klien faktor penyebab penyakit

3. Menanyakan kepada klien mengapa merasa cemas dan tidak berdaya

4. Mengajarkan cara relaksasi untuk mengurangi kecemasan

5. Mengajarkan klien latihan berpikir positif

6. mendiskusikan ketidakberdayaan yang dialami pasien

6. Mengajarkan terapi perilaku
$\mathbf{S}$ : -Klien mengatakan hal yang membuatnya tidak berdaya

-Klien senang diajari terapi

O : Klien menceritakan ketidak berdayaannya -klien terlihat paham dengan penjelasan terpi yang diberikan

\section{A: Ketidakberdayaan (-)}

$\mathbf{P}_{\text {klien : Klien melakukan terapi yang diajarkan pada saat }}$ merasakan tidak berdaya

$\mathrm{P}_{\text {perawat : }}$ terapi kedua selesai 
Tanggal 22 Oktober 2021

jam 13.00

1. Melakukan salam teraupetik

2. membina hubungan saling percaya

3. menanyakan kepada klien tentang perasaannya

4. mengajarkan klien terapi perilaku dan berpikir positif
$\mathbf{S}:$ Klien mengungkapkan perasaan yang ia rasakan klien senang diajari terapi

O : - Klien menceritakan pikiran dan perasaan yang mengganggu.

- Klien terlihat paham dengan yang dijelaskan

A : Koping Individu Tidak Efektif berkurang / tujuan tercapai

P:

- bantu klien melakukan terapi sesuai jadwal

- latihan terapi perilaku

- mengajarkan berpikir positif 
Tanggal 23 Oktober 2021

jam 13.00

1. Melakukan salam teraupetik

2. membina hubungan saling percaya

3. menanyakan kepada klien tentang perasaannya

4. mengajarkan klien terapi perilaku dan berpikir positif
S: Klien mengungkapkan perasaan yang ia rasakan

klien senang diajari terapi

$\mathbf{O}$ : Klien menceritakan pikiran dan perasaan yang mengganggu

klien terlihat paham dengan yang dijelaskan

A : Koping Individu Tidak Efektif

$(-)$

$\mathbf{P}$.

○ bantu klien melakukan terapi sesuai jadwal

- latihan terapi perilaku

○ mengajarkan berpikir positif 


\section{BAB 4 PEMBAHASAN}

Berdasarkan wawancara yang dilakukan oleh penulis. penulis mendapatkan hasil yaitu seorang laki-laki bernama Tn.A, Saat dilakukan pengkajian dirumahnya Tn.A mengatakan sudah menderita RA dan selalu merasa cemas dengan keadaannya setiap kali rematiknya kambuh. Tn.A mengatakan nyeri sendi, setiap beraktifitas bagian badan merasa kebas, saat bernapas napas nya pendek dan terasa sesak, saat dilakukan pengukuran tekanan darah didapatkan hasil 130/90 $\mathrm{mmHg}$.

Pasien memiliki 5 orang anak dan semua sudah menikah, pasien tinggal dirumah dengan istri dan anak yang terakhir. Saat sedang merasa lelah Tn.A bercerita dengan istrinya. Penampilan pasien rapi dan bersih, ramah dan mau menceritakan semua hal yang dialaminya. Saat dilakukan pemberian terapi pasien bisa mengikuti instruksi yang diberikan. Evaluasi yang saya lakukan terapi 1 berhasil dan dilanjutkan dengan pemberian terapi ke 2.

\section{Tahap Pengkajian}

Selama pengkajian dilakukan pengumpulan data dari beberapa sumber, yaitu dari pasien dan tetangga sekitar. Maka penulis melakukan pendekatan kepada pasien melalui komunikasi teraupetik yang lebih terbuka membantu klien untuk memecahkan perasaannya dan juga melakukan observasi kepada pasien. Adapun upaya tersebut yaitu

a. Melakukan pendekatan dan membina hubungan saling percaya diri pada klien agar klien lebih terbuka dan lebih percaya dengan menggunakan perasaan.

b. Mengadakan pengkajian klien dengan wawancara dalam pengkajian ini, penulis tidak menemukan kesenjangan karena ditemukan hal sama seperti: diteori: Kecemasan adalah keadaan emosi dan pengalaman subyektif individu, tanpa objek yang spesifik karena ketidaktahuan dan mendahului pengalamanya yang baru seperti penyakitnya saat ini

\section{Tahap perencanaan}

Perencanaan dalam proses keperawatan lebih dikenal dengan rencana asuhan keperawatan yang merupakan tahap selanjutnya setelah pangkajian dan penentuan 
diagnosa keperawatan. Pada tahap perencanaan penulis hanya menyusun rencana tindakan keperawatan sesuai dengan pohon masalah keperawatan yaitu : Kecemasan.

Pada tahap ini antara tinjauan teoritis dan tinjaun kasus tidak ada kesenjangan sehingga penulis dapat melaksanakan tindakan seoptimal mungkin dan didukung dengan seringnya bimbingan dengan pembimbing. Secara teoritis digunakan cara strategi pertemuan sesuai dengan diagnosa keperawatan yang muncul saat pengkajian. Adapun upaya yang dilakukan penulis yaitu :

1. Klien mengungkapkan ketidakpastian tentang fluktuasi tingkat energi dan bersikap pasif.

2. Klien menunjukan sikap apatis, depresi terhadap perburukan fisik yang terjadi dengan mengabaikan kepatuhan pasien terhadap program pengobatan

3. Klien mengalami ketergantungan pada orang lain yang dapat mengakibatkan ititabilitas, ketidaksukaan, marah dan rasa bersalah. Klien tidak melakukan praktik perawatan diri ketika ditantang. Klien tidak ikut memantau kemajuan pengobatan. Klien menunjukan ekspresi ketidakpuasan terhadap ketidakmampuan melakukan aktivitas atau tugas sebelumnya. Klien menunjukan ekspresi keraguan tantang performa peran.

\section{Tahap Implementasi}

Pada tahap implementasi, penulis hanya mengatasi 3 masalah keperawatan yakni: diagnosa keperawatan Kecemasan, ketidakberdayaan dan koping in efektif merupakan keadaan emosi dan pengalaman subyektif induvidu, tanpa objek spesifik karena ketidaktahuan dan mendahului semua pengalaman yang di alami penyakit DM

\section{Tahap Evaluasi}

Pada tinjauan teoritis evaluasi yang diharapkan adalah :

c. Membina hubungan saling percaya

d. Mengenali dan mengekspresikan emosinya

e. Mampu mengenal ansietas

f. Mampu mengatasi ansietas melalui teknik releksasi 


\section{BAB 5 \\ PENUTUP \\ Kesimpulan}

Berdasarkan uraian pada pembahasan diatas, maka penulis dapat disimpulkan bahwa:

1. Pengkajian dilakukan secara langsung pada klien dan juga dengan menjadikan status klien sebagai sumber informasi yang dapat mendukung data-data pengkajian. Selama proses pengkajian, perawat mengunakan komunikasi terapeutik serta membina hubungan saling percaya antara perawat-klien. Pada kasus Kecemasan : Rheumatoid Arthritis

2. Diagnosa keperawatan yang utama pada klien dengan Kecemasan: Rheumatoid Arthritis

3. Perencanaan intervensi dan implementasi keperawatan disesuaikan dengan strategi pertemuan pada pasien.

4. Evaluasi keperawatan yang dilakukan menggunakan metode subyektif, obyektif, assessment dan planing.

\section{Saran}

\section{Untuk Keluarga}

Diharapkan agar individu dan keluarga bisa mengerti tentang penyakit diabetes melitus, dan meningkatkan perilaku hidup sehat dengan tujuan meningkatkan kualitas hidup.

2. Untuk Masyarakat/Pembaca

Diharapkan kasus dan materi ini dapat dijadikan sebagai bahan ajar dan data untuk menangani dan menghadapi kasus kecemasan pada masalah psikososial. 


\section{DAFTAR PUSTAKA}

1. Marbun, A., Pardede, J. A., \& Perkasa, S. I. (2019). Efektivitas Terapi Hipnotis Lima Jari terhadap Kecemasan Ibu Pre Partum di Klinik Chelsea Husada Tanjung Beringin Kabupaten Serdang Bedagai. Jurnal Keperawatan Priority, 2(2), 92-99. https://doi.org/10.34012/jukep.v2i2.568

2. Syamsudin, Astuti A.D (2021). Literature Review Pengaruh Simplisia Jahe Terhadap Penurunan Nyeri Rheumatoid Artritis. Jurnal Keperawatan, 7(2), Juli 2021 Hal 37-38s

3. Sari D.J.E, Masruroh (2021) Pengaruh Kompres Hangat Jahe Intensitas Nyeri Rheumatoid Arthritis Pada Lansia. Jurnal IJPN, 2(1), Juni 2021

4. PH, L., Susanti, Y., \& Arisanti, D. (2018). Penurunan Tingkat Ansietas Mahasiswa Dalam Menyusun Skripsi Melalui Terapi Generalis Ansietas. Jurnal Ilmu Keperawatan Jiwa, 1(2), 76. https://doi.org/10.32584/jikj.v1i2.150

5. Sianipar N, Pangaribuan R, Tarigan J (2021). Pemenuhan Kebutuhan Aktivitas Pada Lansia Dengan Rheumatoid Arthritis $(R a)$ Di Upt Pelayanan Lanjut Usia Binjai. [Mahesa: Malahayati Health Student Journal, P- Issn: 2746-198x E-Issn 2746-3486, 1(3), 2021] Hal 270-283

6. Darmawan Y.D (2020) Hubungan Self Management Dengan Kualitas Hidup Penderita Rheumatoid Arthritis Di Wilayah Kerja Puskesmas Kecamatan Baki

7. Hulu, E. K., \& Pardede, J. A. (2016). Dukungan Keluarga Dengan Tingkat Kecemasan Pasien Pre Operatif Di Rumah Sakit Sari Mutiara Medan. Jurnal Keperawatan, 2(1).

8. Pardede, J. A. (2020). Standar Asuhan Keperawatan Jiwa Dengan Masalah Kecemasan.

9. Simbolon E.M (2021) Literature Riview: Efektifitas Senam Rematik Terhadap Penurunan Nyeri Sendi Pada Lansia Penderita Reumatoid Arthritis

10. Lubis \& Afif (2014). Tingkat Kecemasan Orangtua dengan Anak yang akan Dioperasi. Jurnal keperawatan padjajaran. 2(3).

11. Pardede, J. A., Hulu, D. E. S. P., \& Sirait, A. (2021). Tingkat Kecemasan Menurun Setelah Diberikan Terapi Hipnotis Lima Jari pada Pasien Preoperatif. Jurnal Keperawatan, 13(1), 265-272.

12. Pardede, J. A., Keliat, B. A., Damanik, R. K., \& Gulo, A. R. B. (2020). Optimalization of Coping Nurses to Overcoming Anxiety in the Pandemic of Covid-19 in Era New Normal. Jurnal Peduli Masyarakat, 2(3), 105-112.https://doi.org/10.37287/jpm.v2i3.128 
13. Stuart, Keliat \& Pasaribu (2016). Prinsip Dan Praktik Keperawatan Kesehatan Jiwa Stuart. Edisi Indonesia (Buku 1). Singapura:Elsevier

14. Pardede, J., Simanjuntak, G. V., \& Manalu, N. (2020). Effectiveness of deep breath relaxation and lavender aromatherapy against preoperative patient anxiety. Diversity and Equality in Health and Care, 17(4), 168-173.

15. Stuart, Keliat \& Pasaribu (2016). Prinsip Dan Praktik Keperawatan Kesehatan Jiwa Stuart. Edisi Indonesia (Buku 1). Singapura:Elsevier

16. Aletaha D, Neogi T, Silman AJ, Funovits, Felson T, Bingham III CO et al. (2010). Rematoid Arthritis Classification Criteria An American College of Rheumatology/European League Against Rheumatism Collaborative Initiative. Arthritis Rheum, 62, $2569-81$

17. Pardede, J. A. (2020). Konsep Ketidakberdayaan. Jurnal Ilmu Kesehatan 6(2)

18. Pardede, J. A. (2022). Koping Keluarga Tidak Efektif Dengan Pendekatan Terapi Spesialis Keperawatan Jiwa.

19. Bresnihan B. (2002). Rheumatoid Arthritis: Principles of Early Treatment. The Journal of Rheumatology, 29(66),.9-12

20. Candra K. (2013). Teknik Pemeriksaan Genu Pada Kasus Osteoarthritis Dengan Pasien Non Koperatif. Academia Edu

21. Choy E. (2012). Understanding The Dynamics: Pathway Involved In The Pathogenesis Of Rheumatoid Arthritis. Oxford University Press on behalf of the British Society for Rheumatology, 51, 3-11

22. Febriana (2015). Penatalaksanaan Fisioterapi Pada Kasus Rheumatoid Arthritis Ankle Billateral Di RSUD Saras Husada Purworejo. Fakultas Ilmu Kesehatan Universitas Muhammadiyah Surakarta

23. Kapita Selekta Kedokteran/editor. Chris Tanto, et al. Ed.4.(2014). Jakarta: Media Aesculapius, 835-839

24. McInnes, I.B., Schett, G. (2011). The Pathogenesis of Rheumatoid Arthritis. N Engl J Med, 365, 2205-19

25. Nainggolan,Olwin. (2009). Prevalensi dan Determinan Penyakit Rematik di Indonesia. Maj Kedokt Indon, 59(12), 588-594

26. Pradana,S.Y. (2012). Sensitifitas Dan Spesifisitas Kriteria ACR 1987 dan ACR/EULAR 2010 pada Penderita Artritis Reumatoid di RSUP Dr. Kariadi Semarang. Fakultas Kedokteran Universitas Diponegoro

27. Putra,T.R., Suega,K., Artana,I.G.N.B. (2013). Pedoman Diagnosis dan Terapi 
Ilmu Penyakit Dalam. Bagian/SMF Ilmu Penyakit Dalam Fakultas Kedokteran Universitas Udayana/RSUP Sanglah

28. Rekomendasi Perhimpunan Reumatologi Indonesia. (2014). Diagnosis dan Pengelolaan Artritis Reumatoid. Perhimpunan Reumatologi Indonesia. ISBN

29. Rudan, I., et al. (2015). Prevalence Of Rheumatoid Arthritis In Low- And Middle-Income Countries: A Systematic Review And Analysis. Journal of Global Health, 5(1), 1-10

30. Suarjana, I.N. (2009). Artritis Reumatoid. dalam Sudoyo, A.W., Setiyohadi, B., Alwi, I., Simadibrata, M., Setiati, S. (editor). Buku Ajar Ilmu Penyakit Dalam. Edisi V, FKUI, Jakarta, 2495-508

31. Sumariyono, H.I. (2010). Predictor Of Joint Damage In Rheumatoid Arthritis. Indonesian Journal of Rheumatology, 3(2), 15-20 